\section{Zika Virus Transmission from French Polynesia to Brazil}

\author{
Didier Musso \\ Author affiliation: Institut Louis Malardé, Papeete, Tahiti, \\ French Polynesia \\ DOI: http://dx.doi.org/10.3201/eid2110.151125
}

To the Editor: Campos et al. (1) reported a Zika virus (ZIKV) outbreak in Brazil in 2015. This response adds complementary data related to the propagation of this mosquitoborne disease.

To date, the largest ZIKV outbreak occurred in French Polynesia during 2013-2014. The outbreak spread to other Pacific Islands: New Caledonia, Cook Islands, Easter Island, Vanuatu, and Solomon Islands (2). The origin of introduction of ZIKV to French Polynesia remains unknown; introduction of ZIKV in New Caledonia was after imported cases from French Polynesia (3); introduction to Easter Island was suspected to have occurred among attendees of the annual Tapati festival, including those from French Polynesia (4). The virus was likely transmitted to New Caledonia, Cook Islands, and Easter Island when infected travelers from French Polynesia were bitten by vectors while on the islands. Frequent travel between New Caledonia and Vanuatu is likely related to the introduction of ZIKV in the latter country.

Phylogenetic studies showed that the closest strain to the one that emerged in Brazil was isolated from samples from case-patients in French Polynesia and spread among the Pacific Islands (1); both strains belong to the Asian lineage. It has been assumed that ZIKV was introduced to Brazil during a World Cup soccer competition in 2014 (5), although no ZIKV-endemic Pacific countries competed. However, in August 2014, the Va'a World Sprint Championship canoe race was held in Rio de Janeiro, Brazil. Four Pacific countries (French Polynesia, New Caledonia, Cook Islands, and Easter Island) in which ZIKV circulated during 2014 had teams engaged in this contest in several categories. These data combined with phylogenetic studies by Zanluca et al. (5) suggest that ZIKV introduction in Brazil may have been a consequence of this event. In areas where potential vectors are present, vigilance should be enhanced to detect imported cases of ZIKV, and laboratory capacity to confirm suspected ZIKV infections should be strengthened.

\footnotetext{
References

1. Campos GS, Bandeira AC, Sardi SI. Zika virus outbreak, Bahia, Brazil. Emerg Infect Dis. 2015 Oct [cited 2016 Jul 7]. http://dx.doi.org/10.3201/eid2110.150847

2. Musso D, Cao-Lormeau V, Gubler D. Zika virus: following the path of dengue and chikungunya? Lancet. 2015;386:243-44. http://dx.doi.org/10.1016/S0140-6736(15)61273-9

3. Dupont-Rouzeyrol M, O'Connor O, Calvez E, Daurès M, John M, Grangeon JP, et al. Co-infection with Zika and
}

dengue viruses in 2 patients, New Caledonia, 2014. Emerg Infect Dis. 2015;21:381-2. http://dx.doi.org/10.3201/ eid2102.141553

4. Schwan K. Zika virus_-Pacific (07): Chile (Easter Island), French Polynesia (07). ProMedmail. 2014 Mar 9 [cited 2016 Jul 7]. http://www.promedmail.org, archive no. 20140309.2322907.

5. Zanluca C, de Melo VCA, Mosimann ALP, dos Santos GIV, dos Santos CND, Luz K. First report of autochthonous transmission of Zika virus in Brazil. Mem Inst Oswaldo Cruz. 2015;110:569-72. http://dx.doi.org/10.1590/0074-02760150192

Address for correspondence: Didier Musso, Institut Louis Malardé, PO Box 30, 98713 Papeete, Tahiti, French Polynesia; email: dmusso@ilm.pf

\section{Schistosomiasis Screening of Travelers from Italy with Possible Exposure in Corsica, France}

\author{
Anna Beltrame, Lorenzo Zammarchi, \\ Gianluca Zuglian, Federico Gobbi, \\ Andrea Angheben, Valentina Marchese, \\ Monica Degani, Antonia Mantella, Leila Bianchi, \\ Carlotta Montagnani, Luisa Galli, Matteo Bassetti, \\ Alessandro Bartoloni, Zeno Bisoffi
}

Author affiliations: Santa Maria Misericordia University Hospital of Udine, Udine, Italy (A. Beltrame, G. Zuglian, M. Bassetti); Sacro Cuore Hospital, Negrar, Italy (A. Beltrame, F. Gobbi, A. Angheben, V. Marchese, M. Degani, Z. Bisoffi); University of Florence School of Medicine, Florence, Italy (L. Zammarchi, A. Mantella, A. Bartoloni); Anna Meyer Children's University Hospital, Florence, Italy (L. Bianchi, C. Montagnani, L. Galli)

DOI: http://dx.doi.org/10.3201/eid2110.150869

To the Editor: Since 2014, many cases of urogenital schistosomiasis acquired in Corsica, France, have been described (1-4). The infections, which all occurred in persons who had bathed in the Cavu River in 2011 or 2013, represent the first cases of autochthonous Schistosoma haematobium infection acquired in Europe since the last reported case in Portugal in 1965 (5). In June 2014, France established a screening program for persons reporting exposure to the Cavu River during 2011-2013. By March 2015, a national surveillance journal had reported 110 autochthonous urogenital schistosomiasis cases in residents of France (6).

We describe the diagnostic work-up for and clinical management of persons from Italy who reported bathing in the Cavu River at least once during 2011-2014. All of the patients had requested screening after learning of the risk for acquiring schistosomiasis after freshwater exposure in Corsica. Exclusion criteria for the study included 